
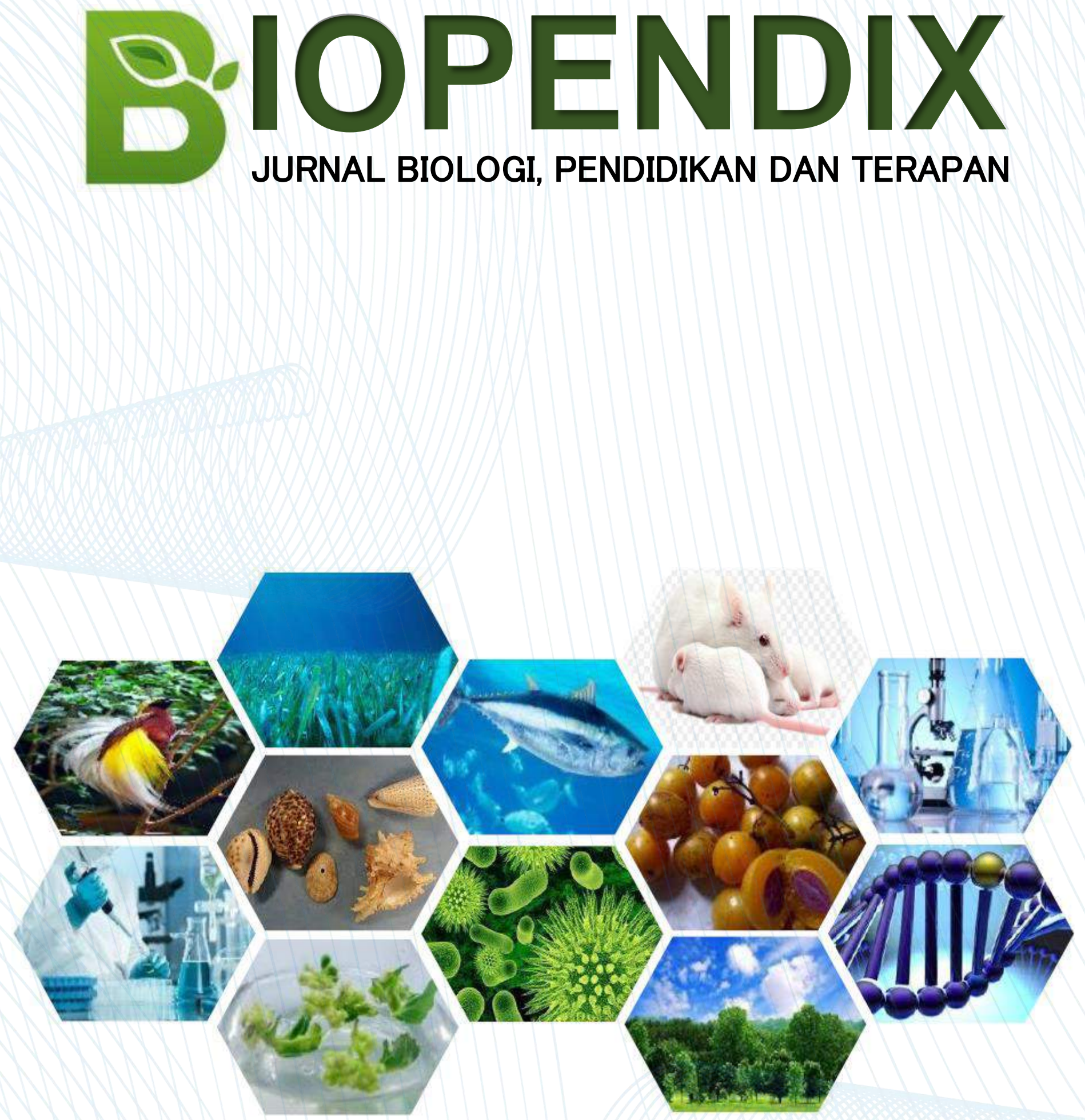

PUBLISHER BY:

BIOLOGY EDUCATION, UNPATTI AMBON - MALUKU 


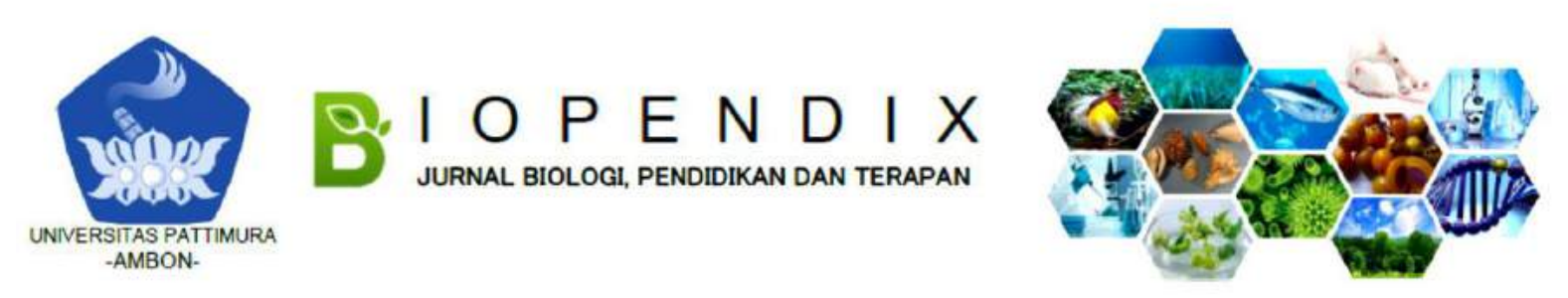

\title{
MODEL PEMBELAJARAN INSIDE OUTSIDE CIRCLE DALAM MENINGKATKAN HASIL BELAJAR SISWA SMA NEGERI 7 AMBON
}

\author{
Rina Juliana Sahuleka ${ }^{1}$, Ali Awan², Stevin Melay ${ }^{* 2}$ \\ ${ }^{1}$ Alumi Program Studi Pendidikan Biologi; ${ }^{2}$ Program Studi Pendidikan Biologi \\ Corresponding Author: Rina Sahuleka; e-mail: rinaj_sahuleka@gmail.com
}

\begin{abstract}
Background: Learning is a process of interaction between teachers and students that is shown to make changes in students' attitudes and mindsets to achieve optimal learning outcomes. The teacher designs learning biology using a contextual approach that is confusing and time-consuming. In learning biology student success is determined by the final outcome of learning.

Methods: The subjects in this study were class XI Science 2 and the data obtained by observation, interviews and learning outcomes tests were analyzed descriptively using a list of initial and final test scores.

Results: The cognitive aspects of the assessment there were 11 students who scored at intervals (80100 ) with a percentage of $68.75 \%$ very good information and 5 students who scored at intervals (6679) with a percentage of $31.25 \%$ good information. Evaluation of affective aspects obtained a percentage of $100 \%$. For the Final Test, there are 12 students who score at intervals (80-100), with a percentage of $75 \%$ and very good information, and 4 students who score at intervals (66-79), with a percentage of $25 \%$ and good information. At the final grade there are 16 students who score at intervals (80-100), with a percentage of $100 \%$ and with very good information.

Conclusion: The application of the Inside Outside Circle (IOC) type of cooperative learning model to the concept of the human excretion system can improve student learning outcomes by achieving KKM 70 .
\end{abstract}

Keywords: Inside Outside Circle Learning Model, student learning outcomes

\begin{abstract}
Abstrak
Latar Belakang: Pembelajaran merupakan proses interaksi antara guru dengan siswa yang ditunjukan untuk melakukan perubahan sikap dan pola pikir siswa untuk mencapai hasil belajar yang optimal. Guru merancang pembelajaran ilmu biologi dengan menggunakan pendekatan kontekstual yang membingungkan dan menyita banyak waktu. Dalam pembelajaran biologi keberhasilan siswa ditentukan oleh hasil akhir pembelajaran.

Metode: Subjek dalam penelitian ini adalah kelas XI IPA 2 dan data yang diperoleh dengan observasi, wawancara dan tes hasil belajar dianalisis secara deskriptif menggunakan daftar nilai tes awal dan tes akhir.

Hasil: Penilaian aspek kognitif terdapat 11 siswa yang memperoleh nilai pada interval (80-100) dengan presentase $68,75 \%$ keterangan sangat baik dan 5 siswa yang memperoleh nilai pada interval (66-79) dengan presentase $31,25 \%$ keterangan baik. Penilaian aspek afektif memperoleh presentase $100 \%$. Untuk Tes Akhir, terdapat 12 siswa yang memperoleh nilai pada interval (80-100), dengan presentase $75 \%$ dan keterangan sangat baik, serta 4 siswa yang memperoleh nilai pada interval (6679), dengan presentase $25 \%$ dan keterangan baik. Pada nilai akhir terdapat 16 siswa yang memperoleh nilai pada interval (80-100), dengan presentase $100 \%$ dan dengan keterangan sangat baik.
\end{abstract}

Kesimpulan: Penerapan model pembelajaran kooperatif tipe Inside Outside Circle (IOC) pada konsep sistem ekskresi manusia dapat meningkatkan hasil belajar siswa dengan mencapai KKM 70.

Kata Kunci: Model Pembelajaran Inside Outside Circle, hasil belajar siswa 


\section{PENDAHULUAN}

Pembelajaran merupakan proses interaksi antara guru dengan siswa yang ditunjukan untuk melakukan perubahan sikap dan pola pikir siswa untuk mencapai hasil belajar yang optimal. Ada berbagai macam proses pembelajaran yang terjadi di sekolah, salah satunya yaitu proses pembelajaran biologi. Ilmu biologi berhubungan dengan cara mencari tahu tentang ilmu kehidupan yang mencakup semua makhluk hidup, sehingga biologi bukan hanya penguasan kumpulan pengetahuan yang berupa fakta-fakta, konsep atau prinsip-prinsip saja tetapi juga merupakan suatu proses penemuan. Prawoto (1992) mengemukakan bahwa, biologi di bangun atas konsep-konsep yang dilandasi pada fakta yang didapat melalui proses metode ilmiah. Namun, dalam pembelajaran biologi tidak semua fakta didapat langsung oleh siswa karena adanya keterbatasan alat bantu (media) dan waktu untuk dapat menghadirkan fakta tersebut. Selain itu, ada juga konsep biologi yang di peroleh dari gejala-gejala yang terjadi pada masa lalu.

Pembelajaran ilmu biologi di SMA banyak terdapat kekurangan-kekurangan yang terjadi. Guru merencanakan pembelajaran ilmu biologi dengan menggunakan pendekatan nyata (kontekstual) yang mengaktifkan siswa karena mengangap pembelajaran yang demikian membingungkan dan menyita banyak waktu. Dalam pembelajaran biologi keberhasilan siswa ditentukan oleh hasil akhir pembelajaran. Hasil akhir pembelajaran siswa sering menjadi persoalan karena nilai masing-masing siswa di bawah standar ketuntasan. Hal ini yang menjadi permasalahan yang di patut diperhatikan oleh guru mata pelajaran. Oleh sebab itu, perlu diberikan alternatif pembelajaran yang dapat mengaktifkan siswa, maka perlu diterapkan suatu sistem yang melibatkan peran siswa aktif dalam kegiatan belajar mengajar guna meningkatkan hasil belajar biologi disetiap jenjang pendidikan.

Untuk meningkatkan hasil belajar siswa untuk menerima tanggung jawab pada proses pembelajaran, yaitu dengan menambah variasi model pembelajaran yang melibatkan siswa secara aktif dan kreatif. Salah satu model pembelajaran yang berkembang saat ini adalah pembelajaran kooperatif. Pembelajaran kooperatif mengkondisikan siswa untuk aktif dan saling memberi dukungan dalam kerja kelompok untuk menuntaskan masalah dalam belajar. Ada salah satu model pembelajaran kooperatif yang dapat digunakan untuk meningkatkan hasil belajar siswa yaitu, model pembelajaran kooperatif IOC (Inside Outside Circle). Model pembelajaran Inside Outside Circle (IOC) adalah pembelajaran dengan sistem lingkaran kecil dan lingkaran besar dimana siswa saling membagi informasi pada saat yang bersamaan dengan pasangan yang berbeda dengan singkat dan teratur (Kagan \& Spencer,1993). Selain itu, siswa bekerja dengan sesama siswa dalam suasana gotong royong dan mempunyai banyak kesempatan untuk mengelolah informasi dan meningkatkan keterampilan berkomunikasi.

SMA Negeri 7 Ambon merupakan salah satu sekolah yang secara terbuka menerima peneliti-peneliti yang ingin melakukan penelitian. Dengan menerima peneliti yang ingin meneliti di sekolah ini, menandakan bahwa sekolah ini begitu antusias mendukung perkembangan dan kemajuan di bidang pendidikan. Sekolah ini pun ingin mendapatkan informasi-informasi terkait dengan dunia pendidikan yang bermanfaat bagi pengembangan mutu pendidikan dan pembelajaran pada sekolah tersebut.

Berdasarkan hasil observasi awal yang dilakukan oleh peneliti bersama Kepala Sekolah dan guru mata pembelajaran biologi, ternyata ada kendala yang dihadapi oleh guru mata pelajaran. Kendala yang di hadapi guru dalam proses pembelajaran, yaitu guru mengajar masih menggunakan model pembelajaran konvensional akibatnya hanya beberapa siswa yang mendominasi diskusi dalam kelompok (aktif). Berdasarkan latar belakang di atas maka peneliti perlu untuk melakukan penelitian terkait "Model Pembelajaran Inside Outside Circle Dalam Meningkatkan Hasil Belajar Siswa SMA Negeri 7 Ambon".

\section{METODE}


Penelitian ini menggunakan jenis penelitian deskriptif untuk mengungkapkan informasi tentang hasil belajar siswa kelas kelas XI SMA Negeri 7 Ambon dengan mengunakan model pembelajaran Inside Outside Cricle. Peneliti melakukan penelitian di SMA Negeri 7 Ambon. Penelitian dimulai pada tanggal 21 Juni sampai tanggal 28 Juni 2019. Subjek dalam penelitian ini adalah siswa kelas XI IPA 2 yang berjumlah 16 Orang. Dalam penelitian ini digunakan tes awal dan tes akhir yang berisi 10 soal PG dan 5 soal esai. Lembar Kerja Siswa (LKS) sebagai bahan evaluasi penerapan pembelajaran. Pengumpulan data dalam penelitian ini di peroleh dengan cara observasi, wawancara dan tes hasil belajar. Penelitian ini menggunakan analisis deskriptif dengan menggunakan daftar nilai tes awal dan tes akhir peserta didik. Hasil Belajar diperoleh dari hasil tes formatif, skor pencapaian diperoleh aspek kognitif menggunakan rumus:

$$
\text { skor pencapaian }=\frac{\text { Skor perolehan }}{\text { Skor maksimum }} \times 100
$$

Aspek kognitif diperoleh dari lembar kerja siswa (LKS). Proses penilaian aspek kognitif pada LKS menggunakan rumus:

$$
\text { skor pencapaian }=\frac{\text { Skor perolehan }}{\text { Skor maksimum }} \times 100
$$

Untuk hasil observasi (aspek afektif dan psikomotor), skor pencapaian diperoleh dengan rumus:

$$
\text { skor pencapaian }=\frac{\text { Skor perolehan }}{\text { Skor maksimum }} \times 100
$$

Selanjutnya, untuk nilai proses (NP) diperoleh dengan cara:

Tabel 1. Klasifikasi Presentase Hasil Tes Awal Pada Kelas XI IPA 2 SMA Negeri 7 Ambon.
$N P \frac{\text { pencapaian kognitif }+ \text { pencapaian afektif }+ \text { pencapaian } \text { psikomotor }}{3} \mathrm{X} 100$

Data yang terkumpul dianalisa untuk memperoleh nilai akhir (NA). Nilai tes formatif $(F)$ : Bobot penilaian dari keduanya adalah $\mathrm{P}=6$ dan $\mathrm{F}=4$.

Nilai akhir ditentukan dengan rumus:

$\mathrm{Na}=\frac{6 \mathrm{P}+4 \mathrm{~F}}{10}$

Keterangan:

NA: Nilai Akhir

$P$ : Nilai proses yang di peroleh dari nilai kognitif LKS, afektif dan psikomotor.

F: Nilai formatif setelah proses pembelajaran.

Selanjutnya Nilai Akhir (NA) Yang menggambarkan tingkat penguasaan minimum. Pada nilai akhir (NA) yang menggambarkan tingkat penguasaan individual terhadap konsep menghargai keputusan bersama dari segi hasil maupun proses.

Hasil dari penilitian ini berupa hasil belajar siswa melalui model pembelajaran Inside Outside Circle (IOC) yang diawali dengan tes awal. Tes awal dilakukan dengan tujuan untuk mengetahui sejauh mana pemahaman atau kemampuan siswa kelas XI IPA 2 mengenai konsep sistem ekskresi sebelum mengikuti proses belajar mengajar. Dengan kriteria ketuntasan minimal (KKM) yang telah di tetapkan oleh sekolah yakni 70 . Tes awal dilakukan pada awal pertemuan dikelas.

\section{HASIL DAN PEMBAHASAN}

\begin{tabular}{cccc}
\hline Interval & Frekuensi & $\mathbf{( \% )}$ & Keterangan \\
\hline $80-100$ & 1 & 6,25 & Sangat baik \\
$66-79$ & 3 & 18,75 & Baik \\
$56-65$ & 8 & 50 & Cukup \\
$40-55$ & 3 & 18,75 & Kurang \\
$30-39$ & 1 & 6,25 & Sangat kurang \\
\hline Jumlah & $\mathbf{1 6}$ & $\mathbf{1 0 0} \%$ & - \\
\hline
\end{tabular}


Tabel di atas menunjukan bahwa kemampuan awal siswa pada tes awal yang terdapat pada Tabel 1 menunjukan bahwa kemampuan awal siswa sangat rendah. Hal ini di dapat dengan diadakan tes awal, sebanyak 1 siswa memperoleh nilai pada interval (80-100) dengan presentase 6,25\% dengan keterangan sangat baik, 3 siswa memperoleh nilai pada interval (66-79) dengan presentase $18,75 \%$ keterangan baik, 8 siswa memperoleh nilai pada interval (56-65) dengan presentase 50\% keterangan cukup, 3 siswa memperoleh nilai pada interval (40-55) dengan presentase $18,75 \%$ keterangan kurang dan 1 siswa memperoleh nilai pada interval (3-
39) dengan presentase $6,25 \%$ keterangan sangat kurang.

Dari data tersebut menunjukan bahwa pengetahuan awal siswa pada konsep sistem ekskresi manusia sangat rendah, maka hasil tes awal pada pertemuan pertama dapat disimpulkan bahwa dari 16 siswa hanya 4 siswa yang memenuhi KKM sedangkan 12 siswa belum memenuhi KKM.

Berdasarkan hasil penilitian yang dilakukan pada SMA Negeri 7 Ambon, kemampuan kognitif siswa dalam proses pembelajaran diketahui dengan cara mengerjakan lembar kerja siswa (LKS).

\section{Tabel 2. Klasifikasi Penilaian Rata-rata Hasil Aspek Kognitif}

\begin{tabular}{cccc}
\hline Interval & Frekuensi & Presentase (\%) & Keterangan \\
\hline $80-100$ & 11 & 68,75 & Sangat baik \\
$66-79$ & 5 & 31,25 & Baik \\
$56-65$ & - & - & Cukup \\
$40-55$ & - & - & Kurang \\
$30-39$ & - & - & Sangat kurang \\
\hline Jumlah & 16 & $100 \%$ & - \\
\hline
\end{tabular}

Berdasarkan LKS yang digunakan untuk melihat hasil kerja siswa, hasilnya pada Tabel 2, terdapat 11 siswa yang memperoleh nilai pada interval (80-100) dengan presentase $68,75 \%$ keterangan sangat baik dan 5 siswa yang memperoleh nilai pada interval (66-79) dengan presentase $31,25 \%$ keterangan baik.

Data dari penilaian aspek afektif diperoleh melalui lembar observasi yang digunakan untuk menilai kemampuan siswa yang meliputi 6 aspek yaitu kejujuran dalam mengerjakan sesuatu, rajin dalam mengerjakan tugas, partisipasi dalam menggemukakan pendapat, penuh perhatian saat mengikuti pelajaran, kerja sama antar sesama teman dan guru.

Tabel 3. Klasifikasi Presentase Hasil Aspek Afektif

\begin{tabular}{cccc}
\hline Interval & Frekuensi & $\mathbf{( \% )}$ & Keterangan \\
\hline $80-100$ & 16 & 100 & $\begin{array}{c}\text { Sangat } \\
\text { baik }\end{array}$ \\
& & & Baik \\
$66-79$ & - & - & Cukup \\
$56-65$ & - & - & Kurang \\
$40-55$ & - & - & Sangat \\
$30-39$ & - & - & kurang \\
\hline Jumlah & 16 & $100 \%$ & - \\
\hline
\end{tabular}

Berikut ini adalah data hasil penilaian aspek psikomotor dimana pada aspek ini digunakan 5 aspek penilaian untuk menilai proses belajar mengajar. 
Tabel 4 Klasifikasi Presentase Hasil Aspek Psikomotor

\begin{tabular}{cccc}
\hline Interval & Frekuensi & Presentase (\%) & Keterangan \\
\hline $80-100$ & 11 & 68,75 & Sangat baik \\
$66-79$ & 5 & 31,25 & Baik \\
$56-65$ & - & - & Cukup \\
$40-55$ & - & - & Kurang \\
$30-39$ & - & - & Sangat kurang \\
\hline Jumlah & 16 & $100 \%$ & - \\
\hline
\end{tabular}

Untuk Aspek Psikomotor, hasilnya terdapat 11 siswa yang memperoleh nilai pada interval (80-100) dengan presentase $68,75 \%$, dan keterangan sangat baik, 5 siswa memperoleh nilai pada interval (6679) dengan presentase $31,25 \%$, dan keterangan baik.

Untuk Aspek Afektif, terdapat 16 siswa yang memperoleh nilai dengan interval (80-
100), dengan presentase $100 \%$ dan keterangan sangat baik

Tujuan melihat hasil belajar siswa adalah untuk mengetahui apakah siswa mampu menguasai indikator pencapaian pada konsep pencemaran lingkungan yang diajarkan guru pada proses belajar mengajar. Tes formatif dilaksanakan pada akhir pertemuan.

Tabel 5 Klasifikasi Presentase Hasil Tes Formatif (Tes Akhir)

\begin{tabular}{cccc}
\hline Interval & Frekuensi & Presentase (\%) & Keterangan \\
\hline $80-100$ & 12 & 75 & Sangat baik \\
$66-79$ & 4 & 25 & Baik \\
$56-65$ & - & - & Cukup \\
$40-55$ & - & - & Kurang \\
$30-39$ & - & - & Sangat kurang \\
\hline Jumlah & 16 & $100 \%$ & - \\
\hline
\end{tabular}

Untuk Tes Akhir, terdapat 12 siswa yang memperoleh nilai pada interval (80100 ), dengan presentase $75 \%$ dan keterangan sangat baik, serta 4 siswa yang memperoleh nilai pada interval (66-79), dengan presentase $25 \%$ dan keterangan baik.

Nilai akhir merupakan hasil belajar siswa, nilai akhir dapat diketahui dari presentase tingkat penguasaan siswa pada nilai proses dari aspek kognitif, afektif dan psikomotor dan presentase penguasaan siswa pada hasil tes (Tes formatif). Tingkat penguasaan setiap siswa berbeda-beda, ini dapat dilihat pada data kualifikasi nilai akhir.

Tabel 6. Klasifikasi Presentase Nilai Akhir

\begin{tabular}{cccc}
\hline Interval & Frekuensi & Presentase (\%) & Keterangan \\
\hline $80-100$ & 16 & 100 & Sangat baik \\
$66-79$ & - & - & Baik \\
$56-65$ & - & - & Cukup \\
$40-55$ & - & - & Kurang \\
$30-39$ & - & - & Sangat kurang \\
\hline Jumlah & 16 & $100 \%$ & - \\
\hline
\end{tabular}


Pada nilai akhir terdapat 16 siswa yang memperoleh nilai pada interval (80-100), dengan presentase $100 \%$ dan dengan keterangan sangat baik.

\section{Tes awal (Pre Test)}

Sebelum proses belajar mengajar berlangsung pada kelas XI IPA 2 dilakukan tes awal. Menurut (Wenno, 2010) tes ini dilaksanakan dengan tujuan untuk menyiapkan siswa dalam proses belajar karena dengan tes awal pikiran mereka akan terfokus pada soal yang mereka kerjakan, untuk mengetahui tingkat kemajuan siswa sehubung dengan proses pembelajaran, untuk mengetahui kemampuan awal yang telah dimiliki siswa mengenai materi yang diajarkan dan untuk mengetahui dari mana seharusnya proses pembelajaran dimulai, tujuan mana yang telah dikuasai peserta didik dan tujuan mana yang perlu mendapat penekanan dan perhatian khusus. Setelah selesai melakukan tes awal ternyata kemampuan awal siswa masih dibawah KKM. Hasil analisis tes awal menunjukan bahwa 8 siswa memperoleh nilai pada interval (56$65)$, dengan presentase $50 \%$ dan dengan keterangan cukup, 3 siswa memperoleh nilai pada interval (40-55), dengan presentase $18,75 \%$ dan dengan keterangan kurang dan 1 siswa memperoleh nilai pada interval (30-39), dengan presentasi 6,25\% dan dengan keterangan sangat kurang.

$\mathrm{Hal}$ ini disebabkan karena saat guru memberikan materi siswa masih kurang memberikan respon dan masih pasif sehingga materi diajarkan guru belum ada hasil yang baik. Tes awal bertujuan untuk memahami sejauh mana kemampuan awal siswa. Kemampuan awal siswa sangat penting diketahui oleh guru sebelum memulai pembelajaran, agar guru dapat menggetahui pemahaman siswa terkait materi yang akan dipelajari. Hal ini sejalan dengan pendapat (Suryobroto, 1996) yang menyatakan bahwa nilai yang diperoleh adalah nol atau hanya sedikit saja yang menjawab dengan betul, ini dapat dimenggerti sebab bahan pembelajaran belum pernah diterapkan.

\section{Penilaian Selama Prosees Belajar Mengajar}

Dalam proses pembelajaran ada 3 aspek penilaian yang dapat digunakan oleh guru dalam menilai kemampuan siswa. Ketiga aspek itu antara lain aspek kognitif, afektif dan psikomotor. Aspek kognitif meliputi kemampuan berpikir, kompetensi memperoleh pengetahuan, pengenalan, pemahaman, konsep tualisasi, penentuan dan penalaran. Aspek afektif meliputi sikap, nilai perasaan, emosi serta derajat penerimaan atau penolakan suatu objek dalam kegiatan belajar-mengajar. Aspek psikomotor merupakan kompetensi melakukan pekerjaan melibatkan anggota badan serta kompetensi yang berkaitan dengan gerakan fisik seperti refleks, keterampilan, gerakan dasar, kemampuan perseptual, ketepatan, keterampilan kompleks (Mulyasa, 2005).

\section{Hasil penilaian aspek kognitf (LKS Inside Outside Circle)}

Mengkategorikan ranah kognitif atas enam jenjang yaitu: pengetahuan, pemahaman, aplikasi, analisis, sintesis, dan evaluasi. Nuryani (2005) menjelaskan pengukuran hasil belajar harus dirancang sedemikian rupa sehingga merupakan hasil belajar seperti pengetahuan menggaplikasikan konsep, atau prinsip serta kemampuan berpikir lainya.

Dalam kegiatan belajar mengajar menggunakan model pembelajaran Inside Outside Circle membuat masing-masing kelompok mendapatkan informasi dari teman-teman kelompok yang menggunakan lingkaran kecil dan lingkaran besar. Sehingga pada penilaian aspek afektif ini menunjukan bahwa 11 siswa memperoleh nilai pada interval (80-100), dengan presentase $68,75 \%$ dan dengan keterangan sangat baik dan 5 siswa memperoleh nilai pada interval (66079), dengan presentase $(31,25)$ dan dengan keterangan baik.

\section{Hasil penilaian aspek afektif}

Penilaian aspek afektif adalah penilaian berkaitan dengan sikap dan nilai yaitu mencakup sikap, minat, perasaan, emosi, dan dimana dalam aspek afektif ini diukur kemampuan seorang siswa dilihat dari sikap yang mendukung atau menolak. 
Arikunto (2006), menjelaskan pengukuran ranah afektif tidak dapat dilakukan setiap saat (dalam arti pengukuran formal) karena perubahan tingkah laku siswa tidak dapat berubah sewaktu-waktu. Pengubahan sikap seseorang memerlukan waktu yang relatif lama. Demikian juga pengembangan minat dan penghargaan serta nilai-nilainya. Sasaran penilaian afektif adalah perilaku peserta didik bukan pengetahuannya.

\section{Hasil Penilaian Aspek Psikomotor}

Pada penilaian aspek psikomotor mencakup kegiatan-kegiatan motorik yang digabungkan dengan kemampuan ketrampilan atau kemampuan bertindak setelah seseorang menerima pengalaman belajar. Sehingga pada penilaian aspek psikomotor menunjukan bahwa 11 siswa memperoleh nilai pada interval (80-100), dengan presentase $68,75 \%$ dan dengan keterangan sangat baik dan 5 siswa memperoleh nilai pada interval (66-79), dengan presentase $31,25 \%$ dan dengan keterangan baik. Dari data tersebut terlihat bahwa tingkat pencapaian KKM dari siswa sudah mencapai standar KKM untuk mata pelajaran biologi pada konsep sistem ekskresi manusia.

Keberhasilan pada penilian aspek afektif dan aspek psikomotor terlihat dalam kegiatan belajar mengajar dimana siswa sangat aktif dalam merespon aspek-aspek yang dinilai. Proses pembelajaran dengan penerapan model Inside Outside Circle (IOC) ini, siswa lebih aktif dalam melakukan kegiatan proses belajar didalam kelas.

\section{Tes Formatif}

Hasil tes akhir yang di peroleh pada kelas XI IPA 2 menggunakan model pembelajaran Inside Outside Circle yaitu 16 siswa berada dalam kualifikasi tuntas. Model pembelajaran Inside Outside Circle dapat mencapai tujuan pengajaran dan merupakan suatu teknik atau cara yang di tempuh guru dalam menyampaikan bahan pelajaran kepada siswa dan melibatkan interaksi yang aktif dan dinamis antara guru dan siswa, sehingga tujuan pembelajaran yang telah ditetapkan dapat tercapai secara efektif dan efisien. Tujuan afektif terdiri dari yang paling sederhana yaitu mempehatikan suatu fenomena sampai kepada yang kompleks dan merupakan internal seoseorang seperti kepribadian dan hati nurani. Dalam mengukur jauh lebih sukar dari kognitif karena menyakut sikap dan apresiasi (Yamin, 2007).

\section{Nilai Akhir}

Setelah mengikuti proses belajar mengajar, perolehan nilai akhir menandakan tingkat keberhasilan yang dicapai siswa. Nilai akhir siswa dalam bentuk deskritif yang diperoleh dari penilaian proses $(6 \mathrm{P})$ dan nilai tes formatif (4F). Hasil belajar tampak sebagai terjadinya perubahan tingkah laku pada siswa, yang dapat diamati dan di ukur dalam bentuk perubahan pengetahuan dan sikap serta ketrampilan, perubahan tersebut dapat diartikan terjadinya peningkatan dan pengembangan yang lebih baik dibandingkan yang sebalumnya. Nilai akhir pada kelas XI IPA 2 dengan model pembelajaran Inside Outside Circle merupakan penggabungan dari penilaian kognitif (LKS dan nilai tes formatif/akhir), penilaian afektif, dan penilian psikomotor. Nilai akhir pada kelas XI IPA 2 dengan model pembelajaran Inside Outside Circle bahwa seluruh siswa telah mencapai ketuntasan belajar sesuai dengan KKM 70 . Dapat dilihat bahwa model pembelajaran Inside Outside Circle dapat menciptakan suasana pembelajaran yang lebih baik, terlebih lagi siswa lebih terlibat dalam proses pembelajaran secara aktif pada aspek kognitif, afektif dan psikomotor.

Pembelajaran dengan menggunakan model pembelajaran Inside Outside Circle berperan penting dalam proses belajar konsep sistem ekskresi. Dapat meningkatkan hasil belajar siswa dengan baik. Suatu aktivitas pembelajaran dapat dikatakan efektif bila proses pembelajaran tersebut dapat mewujudkan sasaran atau hasil belajar tertentu. Pembelajaran dikatakan berhasil dan berkualitas apabila seluruhnya atau setidaknya sebagian besar peserta didik terlibat secara aktif, baik fisik, mental maupun sosial dalam proses pembelajaran (Mursell, 2006). Pembelajaran biologi dengan menerapkan model kooperatif Inside Outside Circle (IOC) memberikan peluang besar kepada siswa untuk berpartisipasi aktif dalam proses mencari informasi sebanyakbanyaknya dan menemukan sendiri 
pengetahuan yang dipelajarinya. Dalam pembelajaran ini, guru hanya berfungsi sebagai fasilitator, mediator, dan motivator, sehingga siswa yang harus aktif dalam membangun pengetahuannya. Model ini memberikan kesempatan bagi siswa untuk berlatih secara mandiri melalui umpan balik dari teman atau guru. Hal ini menyebabkan siswa sangat aktif dalam membagikan informasi kepada temannya yang lain, keterampilan berkomunikasi mereka pun berkembang sehingga tercipta suasana belajar yang menyenangkan. Hal ini sesuai dengan teori belajar sosial yang dicetuskan oleh Albert Bandura yang menyatakan bahwa belajar pada dasarnya adalah upaya aktif individu dalam menemukan pengetahuan dan mengembangkan struktur pengetahuannya dalam berinteraksi (Hergenhahn dkk, 2008).

\section{SIMPULAN}

Berdasarkan hasil penelitian yang diperoleh setelah melakukan analisis dan pembahasan terhadap masalah yang dikemukakan dalam penelitian ini, maka disimpulkan penerapan model pembelajaran inside outsidr circle (IOC) dapat menigkatkan hasil belajar siswa dalam pembelajaran biologi konsep sistem ekskresi manusia kelas XI SMA Negeri 7 Ambon.

\section{DAFTAR PUSTAKA}

Arikunto, S. 2006. Dasar-Dasar Evaluasi Pendidikan. Jakarta: Bumi Aksara

Hergenhahn, B.R. \& Olson, M. H. 2008. Theories of Learning. Edisi Ketujuh. Edisi Bahasa Indonesia. Jakarta:Kencana.

Kagan \& Spencer, 1993. Metode Pembelajaran Inside Outside Circle http://www.kajianpustaka.com/2013/11/ model-pembelajaran-lingkaran-dalamdan.html.

Mulyasa, E. 2005. Menjadi Guru Profesional. Bandung: Rosda karya.

Mursell. 2006. Mengajar dengan sukses. Jakarta: Bumi Aksara.

Nuryani, R. 2005. Strategi Pembelajaran Mengajar Bologi. Malang UM Press.

Prawoto, 1992. Pemahaman Guru-guru Biologi SMA Kota Madya Yogyakarta
Terhadap Strategi Belajar Mengajar (Makalah). IKIP Yogyakarata: Yogyakarta

Suryobroto. 1996, Mengenal Pengajaran disekolah dan Pendekatan baru dalam proses belajar mengajar. Amanta: Yogyakarta.

Wenno, I H. 2010. Metodologi pembelajaran sains berbasis konteks. Yogyakarta: Grafika Indah Offset.

Yamin, H. M. 2007. Profesional Guru \& Implementasi KTSP. Jakarta: Gaung Presada Press. 